The Swedish Rheumatism Association, SRA, and other organisations for disabled persons have joined together in an association called SHIA. SHIA is part of the Swedish aid organisation SIDA. SIDA provides most of the money for the different projects, that SHIA runs. Of special interest for this conference are the projects concerning the new candidate countries to the European Union in the Baltic states.

Many of the organisations within SHIA have their own projects for providing help in different ways, e.g. SRA and organisations concerning diabetes, heart-lungs, asthma-allergy and mentally retarded young people. We all work close together with our "sister-organisations" in the Baltic states.

Together we have a project for establishing the UN Standard rules for equal accessibility in Latvia. During the Soviet time many disabled persons were "hidden" and didn't have the possibilities to come together with other or to come out in the fresh air regularly. Many persons still don't have the means we have for daily living and for going out, but things are now changing very quickly for the better.

The SRA has, together with the corresponding organisation in Latvia, a project to establish a democratic organisation for, and led by, patients. It all started with some doctors and nurses from Latvia, who came to Stockholm to study rheumatologic care. We met with them and told them about how patient organisations, and SRA in particular, work in Sweden, and it was then decided that SRA should help them to establish a patient organisation in Latvia. We have allowed money in our own budget for this, and we also cooperate with SHIA. I'm sorry to say that SIDA has cut down our allowances, so we have to choose very carefully what we can afford to do!

The Latvian organisation, LKLSSB, was founded only three years ago. They now have some hundred members and are represented in eight Latvian regions. They offer a lot of activities for their members: lectures, study groups, excursions etc. They also work with/for young people in their organisation and also cooperate with Unga Reumatiker (Young Rheumatics) in Sweden.

Some of our Swedish "ombudsmen" have been in Latvia to help our Latvian friends to establish the organisation, e.g. with list of members, how to run a democratic association, computerwork, how to write/translate and print brochures and booklets, and how to engage media and politicians to help in information and legislation etc.

In our common work we have also found, that we have a lot to learn from our Latvian friends. They are not stuck in traditions and old habits, they have new fresh ideas, and as they start "from scratch" they can choose priorities and build up a new society with better possibilities for disabled persons.

I have taken part in this project for two years now, and it has made a great impression on me to see the progress and the enthusiasm in the Latvian work!

\section{SP0165 THE ARTHROSIS PROJECT - A THREE YEAR INFORMATION PROJECT IN COOPERATION WITH THE FEDERATION OF SWEDISH FARMERS}

IM Grundin. Board of the Arthrosis/Spondylosis Disease Group, The Swedish Rheumatism Association, Sundbyberg, Sweden

10.1136/annrheumdis-2001.1263

The Swedish Government has granted the Swedish Rheumatism Association financial support from the Inheritance Fund to to be used for the purpose of disseminating information about arthrosis. The project is also sponsored by MSD, Pharmacia and Pfizer. The aim of the project is to increase the individual's knowledge of arthrosis and to contribute to a better way of life for people with arthrosis.

A further aim is to provide information to the general public and medical staff. We also address outselves to patients with an arthrosis diagnosis and those who belong to risk groups, e g to athletes. The working methods of the project are creative - from the traditional study circle to theatre performances and the production of images and written material. We combine aims and mean, and the creative work is carried out among members and their relatives in our local organisations nationwide.

Project activities

"Study circles to increase the individual's knowledge of arthrosis

"Special "Arthrosis days", information to the public, athletics movement and medical and health services

"Information campaigns in conjunction with local arrangements, fairs and exhibitions, etc.

*The compilation of a study material which illustrates what living with arthrosis is like and containing a substantial section covering both body and soul Local working groups will act as test groups.

*What is arthrosis, research into arthrosis, alternative methods of treatment, prevention, rehabilitation, training, personal and sexual relations

*Writer's workshops - writing one's story in prose or poetry as a basis for a manuscript and/or an anthology

"Preparing a theatre performance

"Special, or separate, exhibitions about arthrosis and the Rheumatism Association, arts, images, sculptures, etc. in different techniques

Working constructively and together gives participants strength and a feeling of togetherness.

Special "Arthrosis days" with professional lecturers giving audiences all available information about arthrosis. Advertisements in daily newspapers and local placarding together with invitations addressed directly to selected groups are methods to attract listeners. At the "Arthrosis days" participants will be recruited to Arthrosis School study circles. Study circle leaders will be recruited from our own ranks and will be given specific training.

The project organisation: A project leader working full-time for 3 years, a steering-group mandated to decide on time, resources and quality issues, reference groups and a groups of researchers to check the project products. The project started in July 2000 in five pilot counties to gather experiences for the benefit of the rest of the country. Recruitment of participants will take place in cooperation with our local associations, the Federation of Swedish Farmers, other local organisations and at local health-care centres. 


\section{Evaluating and improving the quality of information for patients}

\section{HP0032 PROBLEMS REPORTED BY PERSONS WITH RHEUMATIC DISEASES}

MA Larsson, AM Andersson, M Aronsson, R Holtin, L Olausson, M Thyberg. Department of Pharmacy, Apoteket AB, Stockholm, Sweden

\subsection{6/annrheumdis-2001.1264}

Background Since 1991, Apoteket AB (the national corporation of Swedish pharmacies) has conducted so called "theme years", focusing on one widespread disease each year, in order to improve drug use. In 2002, Swedish pharmacies will pay special attention to persons with Rheumatic disorders. To prepare for this, we wanted to learn more about the problems associated with these diseases.

Objectives In order to identify disease-related difficulties in this group of patients, a Problem Detection Study (PDS) was performed. A PDS study not only identifies problems, it also ranks the problems according to how troublesome the patients find them.

Methods Initially, interviews with individuals and groups of patients were performed in order to identify all problems. This qualitative step identified 116 different problems. A questionnaire based on the problems was distributed to 950 patients in Sweden. The patients were to give each problem a grade, from 0 (no problem at all) to 3 (large problem). The average grade for each problem was calculated and a list of all problems, ranked by their average grade, was generated. The problem with the highest average was the worst one.

Results $75 \%$ of the 950 patients included answered the questionnaire. This large response rate may be due to an eager among these patients to improve their situation. Problems regarding everyday life were found most troublesome. The largest problem was "It is frustrating that I' $\mathrm{m}$ unable to do everything I wish to, due to my RD". The average grade for this problem was 2,5, which is very high compared to results from similar studies on other groups. The top 50 problems were further analysed, and divided into six categories. Many large problems were connected to everyday life. Problems regarding understanding, from others and from the community, were also important, as well as problems concerning the use of drugs and lack of information. The five subgroups, RA, Arthritis, SLE, Mb Bechterew, Fibromyalgia had very similar experiences, although the latter group differed to some extent.

Conclusions These results are important in several ways. First, they indicate what measures pharmacists can take to solve some of these problems. For instance by counselling in the pharmacies or by information to relatives and others close to the patients. Second, the results will help pharmacists understand these patients better and thereby improve their ability to meet the patients professionally. The study is also of great value in the production of material for continuing education of the Swedish pharmacists.

\section{SP0177 PARTNERSHIP IN ACTION - HOW PATIENT AND PROFESSIONAL ORGANISATIONS ARE WORKING TOGETHER IN THE UK}

S Edwards. British League Against Rheumatism, (An Umbrella Group for 23 Support and Professional Organisations in the Field of Musculoskeletal Conditions), London, UK

\subsection{6/annrheumdis-2001.1265}

Background With the advent of patient empowerment and selfmanagement, it is more important than ever that people with arthritis/rheumatism and those who treat them understand each others' needs and are able to work together. National organisations of patients and professionals have an important role to play in promoting partnership and mutual understanding.

BLAR is an umbrella group which brings patient and professional organisations together to work for better services for people with arthritis/rheumatism in the UK. We have 23 Member organisations. We promote partnership and communication at a local and national level through a number of ways, for example: A multi-disciplinary project to agree and audit patient-centred standards of care.

Establishing local networks of service users, health professionals and patient groups.

Joint parliamentary lobbying for higher priority for arthritis/ rheumatism.

Joint policy development on issues of mutual concern.

Workshops and meetings for service users and professionals to exchange information and best practice.

Results These projects have been very successful, and have demonstrated that partnership can be beneficial to both patient and professional organisations. We have also learned that by working together, we strengthen our voice. Partnership is not possible on every issue, and there will always be differences of opinion. However, we have succeeded in building lasting partnerships on key issues.

\section{Health professional and education}

\section{HP0033 DEVELOPMENT OF A SYSTEM OF NETWORKS AND CONTINUING EDUCATION FOR PHYSICAL THERAPISTS REGARDING THE TREATMENT OF PATIENTS WITH RHEUMATIC DISEASES: THE FYRANET PROJECT}

${ }^{1} \mathrm{~J}$ Verhoef, ${ }^{2} \mathrm{R}$ Hoekman, ${ }^{3} \mathrm{M}$ Bakker, ${ }^{4} \mathrm{HM}$ de Vries-van der Zwan, ${ }^{2,5} \mathrm{FGJ}$ Oosterveld, ${ }^{1,6}$ TPM Vliet Vlieland. 'Department of Physical Therapy; ${ }^{2}$ Department of Physical Therapy, Medisch Spektrum Twente, Enschede; ${ }^{3}$ School of Physiotherapy, Leiden; ${ }^{4}$ Comprehensive Cancer Center, Leiden; ${ }^{5}$ Saxion School of Physiotherapy, Enschede, The Netherlands; ${ }^{6}$ Department of Rheumatology, Leiden University Medical Center

10.1136/annrheumdis-2001.1266

Objectives It has been observed by physical therapists and patients that treatment of patients with rheumatic diseases by physical therapists is hampered by a lack of specific knowledge and technical and communicative skills. Moreover, co-ordination between different health professionals involved in the treatment has been perceived as not optimal. Aim of the study was to set up a system of continuous improvement of specific knowledge and skills regarding the physiotherapeutic treatment of patients with rheumatic diseases and to start networks of physical therapists working in primary care, hospitals and rehabilitation centres. 